\title{
Assessing Induction and Retention of Teachers in Biakoye District in the Volta Region, Ghana
}

\author{
Joseph Appiah \\ E. P. College of Education, Department of Social Science, P. O. Box AM 12, Amedzofe, Volta Region-Ghana
}

\begin{abstract}
The study assessed the induction of teachers in basic schools and the effects of the induction course on teacher retention in the Biakoye District. To achieve this, a sequential mixed approach was chosen with the use of survey and case study designs. A simple random sampling procedure was used to select 220 teachers from ten (10) basic schools in the Biakoye District for the quantitative phase. Questionnaire was used to collect data from the 220 teachers. In terms of the qualitative phase on the other hand, the convenience sampling procedure was used to select three (3) Head Teachers in addition to the District Director of Education for the study. With this, the semistructured interview guide was used to collect data. Both data sets were analysed using the thematic analysis and regression. The study revealed that the induction programme helped teachers to develop skills in technological orientation and improved performances. It was therefore, recommended that the Colleges of Education should institutionalise induction policy, introduction of mentor-mentee relationship, training and capacity building of Head Teachers in induction programmes, investment in induction training programmes for new teachers and coordinating and alignment of induction programmes among providers.
\end{abstract}

Keywords: Teachers, Induction, Retention, Human Resource, Job Performance

DOI: $10.7176 / \mathrm{JEP} / 11-26-03$

Publication date:September $30^{\text {th }} 2020$

\section{Introduction}

Generally, human resource training and development has been viewed as one of the core fundamentals in developing quality workforce in every sector and that there is a close correlation between the availability of development opportunities in an organisation and the performance of the people working with it. According to Flippo (1984), development has to do with the increase of skills through training that is necessary for proper job performance. To ensure quality education, there is the need to provide sustained and continuous competent teachers who are able to steer the educational development of students. However, one of the most important challenges in the field of education is developing a qualified workforce and creating work environments that sustain special educators' involvement and commitment. In this regard, Smith-Davis (2000) notes that for more than two decades, issues related to training and teacher career development have been of concern to policy makers and administrators who work to recruit and retain educators.

One of the most adopted training and development approaches in the field of education is the creation of induction training opportunities for teachers. For decades, education researchers and reformers have drawn attention to the challenges encountered by newcomers to school teaching. According to Edmunds and Smith (2001), induction for new teachers is the term used to describe a process or series of processes a beginning teacher experiences so as to improve the skills necessary in being successful in the assigned teaching environment. Thus, in the context of teacher training and development, induction is defined as a stage within the continuum of teacher professional learning. Wong (2005) further defines induction process as a comprehensive process of sustained training and support for new teachers, a comprehensive coherent, and sustained professional development process that is organised by a school district to train, support and retain new teachers. Therefore, induction could then seamlessly progress them into a lifelong learning programme.

There are three categories of induction programmes; these include orientation programmes, those aimed at performance improvement and induction programmes for certification. Seyfarth (1996) distinguishes between these three categories of induction programmes. The Orientation Programmes of induction are aimed at providing new teachers with essential information. These programmes are of short duration and the emphasis is on information dissemination. According to Steyn and Schulze (2005), the information provided may include a tour of the school, the vision and mission of the school, policies and procedures, roles and responsibilities of the teacher, resources and school activities as well as record keeping. Performance improvement programmes is another type of induction programme for newly recruited workers. This category of induction aims at improving the instructional effectiveness of beginning teachers. Workshops that are arranged for newly recruited teachers cover discipline and classroom management procedures, performance assessment procedures, orientation to district curriculum, conversations with subject-area specialists and assistance in preparing a professional development plan (Kempen, 2010). Also, is the induction for certification? This type of programme operates under state mandate and is primarily evaluative in nature, but evaluation is combined with limited assistance. Beginning teachers are required to demonstrate their mastery of specified teaching competencies in order to receive a permanent teaching 
certificate.

Induction serves as an appropriate link in the teacher development process and impacts on new teachers' expertise, professional development, job satisfaction and retention rates. Teachers tend to respond positively to the demands of their job when adequate orientation is given to them. This induces them to stay on the job (Ingersoll \& Kralik, 2004). Since teacher development occurs in stages, the survival of the fittest approach is unsuitable for the success and retention of beginning teachers. Consequently, educational administrators in many parts of United States and other developed countries have adopted induction and mentoring programmes for beginning teachers. There is a growing interest in this form of support, guidance and orientation for novice teachers (Ingersoll \& Smith, 2004).

Ghana, like most developing nations, is yet to establish a formal educational policy on induction and mentoring for beginning teachers (Cobbold, 2007). Although the Ministry of Education and the Ghana Education Service (GES) do not have an official policy on teacher induction, they advise heads of institutions to give induction to new members of staff (Ministry of Education, 1994). The Ministry of Education (MOE, 1995) noted that the avenues for teacher education through the provision of induction are limited. The MOE; however, cautioned against externally designed induction activities, indicating that these are not effective as they are externally designed without the involvement of teachers and are more seriously presented in a deductive manner which does not help the teacher to deal with the actual classroom situations. The Ministry of Education evaluation of induction training programmes indicated that there are several problems concerning the organisation, content and effectiveness of induction training.

\section{Statement of the Problem}

Training programmes play a crucial role as it is through training that teachers' skills, development and attitudes can be changed for the better. Therefore, training programmes are vital to teachers and to governments to pass on the latest innovations in teaching methods/strategies and new curricula (David, 2001). In recent years, much attention has been given to the quality of teacher education programmes and the conditions for effective programmes for continuous professional development whereas less attention has been given to the design of effective induction programmes that support teachers in their transition from their initial teacher education into working life in schools (Adentwi, 2005). Thus, the issue of support of teachers in their induction phase is of particular concern in a context of shortages of teaching skills.

In Ghana, the Ministry of Education and the Ghana Education Service do not have an official policy on teacher induction, they advise heads of institutions to give induction to new members of staff (Ministry of Education, 1994). However, the concept of induction has lasted for a long time, the literature on the impacts of induction for newly posted teachers on teachers' retention is still scanty. My personal observation and findings from studies conducted in Biakoye District suggest that most of the teachers posted to the district came and felt dejected; hence their eagerness to leave the district.

The impact of induction programmes for newly posted teachers on the retention of teachers is yet to be verified systematically by any empirical approach in the district. Against these backgrounds, it is important to assess the induction of newly posted teachers in basic schools and its implications for teacher retention in the district. In other words, would newly posted teachers involved in induction programmes have more positive attitudes toward teaching and plan to continue in the profession longer than those who have not participated in induction programmes. This is necessary since the quality of human capital of any nation depends upon the quality of education it offers, and the quality of education given is also determined by the quality of teachers who teach.

\section{Objectives of the Study}

Specifically, the study seeks to:

- Examine the benefits of induction programmes to teachers in the Biakoye District.

- Assess the impact of induction on the retention of teachers in the Biakoye District?

Specifically, the study is useful to government and other stakeholders in the educational sector such as the Ministry of Education (MOE), the Ghana Education Services (GES) as well as Unit Schools on the alternative approaches in administering induction training to teachers, especially the newly posted teachers. Additionally, this study would bring to bear the relevance of these training programmes on the career retention of the teachers to help contribute to policy on how to rectify anomalies with regard to the administration of induction training programmes for newly posted teachers. Thus, the implications of this study for policy making is that the findings of the study will serve as a case study that will guide authorities, stakeholders and/or policy makers in the educational sector in the adoption of a formal policy or framework on induction of newly posted teachers in the country. The findings from the study will also give some directional indicators for future research regarding training and development policy of the Ghana Education Service and teacher career development. Thus, the study will add to the existing literature on induction of newly posted teachers and teacher retention to serve as a useful guide and reference material for researchers, scholars and academicians. 


\section{Literature Review}

\section{Concept of Induction Programmes}

Induction begins on the first day the new employee is on the job (Rogers \& Olmsted, 1957). This type of training is aimed at acquainting the new employee with the organisation and its personnel. Concerning the characteristics of a new employee, Van Dersal (1962) noted that when people start to work in an organisation for the first time, they are eager to know what sort of outfit they are getting into, what they are supposed to do, and whom they will work with. They are likely to be more attentive and open-minded than experienced employees. In fact, the most favourable time for gaining employees' attention and for moulding good habits among them is when they are new to the job.

Teachers are identified as people who influence the quality of education in schools (Barber \& Mourshed, 2007). Therefore, for policy makers working on improving educational systems, it is important to develop policies that support the professional development of teachers. According to Klu (1997), teacher education is in three phases, namely, pre-service, induction, and in-service, all of which must be seriously executed to enable the teacher to be abreast of the demands of the job. Duodu (2002) also postulates that effective teacher education depends on the quality of instruction given in training institutions and the induction given to them at their new stations. On the other hand, Smith and Ingersoll (2004) distinguish between teacher induction and pre-service preparation and inservice training, and regard teacher induction as a support for the transition into full professional teacher status and survival of a novice teacher.

Additionally, European Commission Staff Working Document SEC 538 final (2010) indicates that professional development of teachers is a lifelong process that starts at initial teacher education and ends at retirement. Generally, this lifelong process is divided in to specific stages. The first stage concerns the preparation of teachers during initial teacher education, where those who want to become teachers, master the basic knowledge and skills. The second stage is the first independent steps as teachers, the first years of confrontation with the reality to be a teacher in school. This phase is generally called the induction phase, while the third phase is the phase of the Continuing Professional Development of teachers that have overcome the initial challenges of becoming a teacher. According to European Commission Staff Working Document SEC 538 final (2010), all teachers will go through these phases. However, the quality of their development will depend strongly on the support that is given to them in each of these phases.

In recent years, much attention has been given to the quality of teacher education programmes and the conditions for effective programmes for Continuous Professional Development whereas less attention has been given to the design of effective induction programmes that support teachers in their transition from their initial teacher education into working life in schools. Thus, the issue of support of teachers in their induction phase is of particular concern in a context of shortages of teaching skills and, in some countries, of large numbers of young teachers leaving the profession.

Induction must, furthermore, build on efforts of initial teacher education (Hargreaves \& Fullan, 2000). Teacher induction as defined by Huling-Austin (1990) is a planned programme intended to provide some systematic and sustained assistance, specifically to beginning teachers, for at least one year which offers ethical, professional, and personal assistance. Thus, teacher induction is a systematic organisational effort to help new teachers adjust readily and effectively to their new assignments, while realising personal and professional fulfilment.

\section{Importance of Teacher Induction Programmes}

Teacher induction programmes are believed to benefit beginning teachers and students in many different ways. Although teacher induction programmes were initially implemented to assist in the improvement of teaching quality, beginning teachers also improved in self-confidence and classroom management skills (Joerger \& Bremer, 2001). Induction programmes help new teachers establish effective classroom management procedures, routines, and instructional practices. They develop within the teacher sensitivity and an understanding of the community as well as their passion for lifelong learning and professional growth. Also, successful induction programmes promote unity and teamwork among the entire learning community (Wong, 2002). The value and importance of induction programmes should not be underestimated (Darling-Hammond, 2003), as they aim at raising retention rates of new teachers by improving attitudes, feelings of efficacy, and instructional skills. Bush and Middlewood (2005) identifies the main purposes of induction as that of socialisation, enabling the new person to become a contributing member of the organisation and cultivating within the new teacher an appreciation of the core values and beliefs of the institution. According to Vierstraete (2005), the purpose of induction programmes includes:

- Providing continuing assistance to reduce the problems common to beginning teachers

- Supporting development of the knowledge and the skills needed by beginners to be successful in their initial teacher positions

- Integrating beginning teachers into the social system of the school, district, and community; and

- Providing an opportunity to analyse and reflect on teaching through a coaching relationship with veteran 
teachers.

\section{Impacts of Induction on Teacher Retention}

A good teacher induction programme has the potential to increase the retention rate of new teachers and improve the quality of the instruction they deliver (Huling-Austin, 1990; Lawson, 1992). Organised induction assistance programmes help in the retention of promising beginning teachers, many of whom leave teaching in frustration during their first years on the job (Viadero, 2005). According to Joerger and Bremer (2001), teachers involved in induction programmes have more positive attitudes toward teaching and plan to continue in the profession longer than those who have not participated in induction programmes. Thus, Wong (2002) noted that the success of an induction programme is measured by the retention rate of teachers. Therefore, the more quality components of induction experienced by a new teacher, the lower the probability of turnover. For example, ninety-five percent of beginning teachers who are nurtured through an induction programme experience success during their initial years (Menchaca, 2003). Similar to Menchaca (2003), Smith and Ingersoll (2004) report that the more components of induction experienced by a novice teacher, the lower the predicted probability of turnover. Liu and Meyer (2005) report that teacher induction programmes were correlated with high teacher morale and career commitment. Thus, professional development opportunities are a key factor in a teacher deciding to remain in teaching (Yost, 2006).

\section{Methods}

However, in relation to the objectives of this study, the selected approach is an adapted version of the sequential explanatory mixed method approach (Creswell 2009) where survey and case study were used for the quantitative and qualitative phases

The study population consisted of all Teachers and Head Teachers in the Biakoye District. At the quantitative stage, two hundred and twenty (220) teachers were randomly selected from ten (10) schools and three (3) Head Teachers were conveniently selected and District Director of Education was purposively sampled for the study.

By way to establish validity of the instruments, three (3) independent raters with key knowledge in administration and analysis of data were given the instruments for a thorough check for flaws and problems in the study. Remarks from the independent raters were favourable and no massive changes were made in the instruments. Moreover, to grant the content validity of the instrument, it was given to two (2) retired head teachers, who had knowledge about the case to scrutinize the instruments. Steps to check reliability of the study was asking the interviewees to either confirm or disconfirm their statements after each interview has been transcribed.

The questionnaire was analysed using frequency, percentage and multiple regression. The analysis was calculated using an alpha level of .05 to achieve statistical significance. The purpose of maintaining the alpha level was to eliminate the potential of a Type I error. In addition, the beta level was also maintained in order to eliminate the potential for a Type II error. The researcher chose standard regression model for the study because it allowed all variables to be entered into the regression equation, and at the same time, it allowed for each independent variable to be analyzed in terms of its impact upon the dependent variable after all other variables have been entered into the regression equation. In addition, content thematic analysis was used to analysed the semistructured interviews.

\section{Result and Discussion}

In this section, the results of the data that were analysed were discussed according to the research objectives set for the study. The table below shows the responses in terms of figures provided by respondents...

Table 1-Benefited from an Induction Programmes

\begin{tabular}{lcccccc}
\hline & \multicolumn{2}{c}{ District } & \multicolumn{2}{c}{ Circuit } & \multicolumn{2}{c}{ School } \\
\cline { 2 - 7 } Responses & No. & \% & No. & \% & No. & \% \\
\hline Yes & 115 & 52.3 & 53 & 24.1 & 85 & 38.6 \\
No & 105 & 47.7 & 167 & 75.9 & 135 & 61.4 \\
\hline Total & 220 & 100 & 220 & 100 & 220 & 100 \\
\hline
\end{tabular}

Source: Field Survey, Appiah (2017)

The results in Table 1 shows that more than half $(52.3 \%)$ of the respondents benefited from the induction programme at the District level. This implies that there is some growing interest in the orientation for novice teachers as observed by Ingersoll and Smith (2004). However, at the Circuit level and School levels, less than half of the respondents benefited from inducation programmes. At the Circuit level, 75.9 percent have never benefited from any induction programme, suggesting that circuit officers have not made much effort in getting their newly posted teachers inducted. At the school level, similar trends were observed although about 38.6 percent of the head teachers have made some attempts to get their newly posted teachers inducted.

The less effort by some heads of schools in organising the induction programmes could be explained by the assertion that some do not have the requisite skills in organising induction programmes: One of the newly posted teachers lamented that the head teachers even do not know how to organize the induction programme. However, 
a major issue which emanated from the interviews with the head teachers in relation to their inability to organise induction programmes for newly posted teachers was limited resources including funds. One of the head teachers stated:

Organising an induction programme for newly posted teachers is not that easy since the purpose could be for orientation or performance or both. In relation to orientation, we usually do not need any resources. However, in terms of the performance component, you usually will need some instructional materials which in most cases we do not have.

\section{Effectiveness of the Induction Programmes}

This section explored the effectiveness of the induction programmes organised for the teachers who responded to the questionnaire. This was essential to determine if the induction programmes have any bearing on the teaching outcomes of the teachers. Table 2 shows the effectiveness of the induction programmes and their commensuration with the teaching outcomes of the newly posted teachers.

Table 2-Effectiveness of Induction Programme for Teaching Outcomes

\begin{tabular}{lcc}
\hline Responses & Frequency (No.) & Percent (\%) \\
\hline Very Effective & 194 & 88.2 \\
Partially Effective & 22 & 10 \\
Ineffective & 4 & 1.8 \\
\hline Total & 220 & 100
\end{tabular}

Source: Field data, Appiah (2017)

Table 2 shows that almost $194(88.2 \%)$ of the respondents who benefited from the induction programmes rated the programmes as very effective in enhancing their teaching outcomes. This means that even though the induction programmes seem to focus more on orienting the newly posted teachers to the school environment as compared to enhancing their performance, the programmes have been very effective in the teaching outcomes of the teachers. The findings support the assertion of Darling-Hammond (2003) who posits that induction programmes improve the instructional skills of newly trained teachers.

The study further examined if the rating of the effectiveness of the induction programme on the teaching outcomes of the teachers was dependent on their demographics. The chi-square statistical tool was adopted in analysing the data that were measured categorically.

Table 3-Rating Across Demographics

\begin{tabular}{lccc} 
& & Degree of Freedom & \\
Demographic variables & Chi-square $\left(\chi^{2}\right)$ & 2 & Significance $(\mathrm{p})$ \\
\hline Gender & 16.940 & 6 & 0.000 \\
Age & 7.426 & 6 & 0.283 \\
Education & 12.665 & 6 & 0.049 \\
Teaching in the district & 11.701 & 6 & 0.069 \\
Teaching in the school & 10.365 & 0.110 \\
\hline
\end{tabular}

Source: Field data, Appiah (2017)

In Table 3, it is noted that gender and educational background have had very significant impact on respondents' rating of the effectiveness of the induction programmes on their teaching outcomes $(p \leq 0.05)$. In other words, in the exception of gender and educational backgrounds, none of the demographic characteristics of the respondents influenced their rating of the effectiveness of the induction programmes on their teaching outcomes as newly posted teachers. Based on this, the study further performed the standardised residual in identifying the cells among the gender and educational background that had the major contribution to the ratings. Using a level of significance of 0.05 , the critical value for a standardized residual would be -1.96 and +1.96 , hence using standardized residuals, only the cells on the female was the significant contributor to the chi-square result. While more than half $(53.6 \%)$ of the females rated the effectiveness of the programmes on their teaching outcomes as very effective, less than 10 percent $(9.1 \%)$ of the males rated same. The study analysed the specific ways in which the inductions have impacted on the newly posted teachers. This was done using the relative important index (RII) and the weighted mean.

$$
\text { Weighted Mean }=\frac{\sum w}{N} \text { and RII }=\frac{\sum w}{A N}
$$

Where $w$ is the weighting given to each factor by the respondents, ranging from one (1) to five (5), $A$ is the highest weight (i.e. 5 in the study) and $N$ is the total number of respondents that benefited from the training (220). Table 4 shows the weights across the five factors. 
Table 4-Weighting of Impacts of Induction Programme

\begin{tabular}{lcccccc}
\hline Weight Factors & 1 & 2 & 3 & 4 & 5 & Total \\
\hline Developed skills in profession & 0 & 0 & 20 & 75 & 125 & 220 \\
Technologically oriented & 107 & 72 & 41 & 0 & 0 & 220 \\
Improved performance & 43 & 21 & 43 & 72 & 41 & 220 \\
Success in teaching environment & 0 & 25 & 30 & 82 & 83 & 220 \\
Knowledge on district curriculum & 54 & 125 & 41 & 0 & 0 & 220 \\
\hline
\end{tabular}

Source: Field data, Appiah (2017)

Using the weights in Table 4, the relative important index and the ranking are shown in Table 5. A higher relative important index (RII) suggests the most important impact of the training held for the newly posted teacher. The ranking is as follows: Rank $1=$ Least Important Impact and Rank $5=$ Most Important Impact.

Table 5-Ranking of Impacts of the Training Programmes

\begin{tabular}{|c|c|c|c|}
\hline Factors & Weighted Mean & RII & Rank \\
\hline Developed skills in profession & 4.48 & 0.90 & 5 \\
\hline oriented & 1.70 & 0.34 & 1 \\
\hline Improved performance & 3.21 & 0.64 & 3 \\
\hline Success in teaching environment & 4.01 & 0.81 & 4 \\
\hline Knowledge on district curriculum & 1.94 & 0.39 & 2 \\
\hline
\end{tabular}

Source: Field Survey, Appiah (2017)

The analysis of the relative important impact of the in-service training programme shows that the most important impact derived from the training programme is the development of the skills of the teachers in relation to their teaching profession ( $\mathrm{RII}=0.90)$ followed by improvement in the skills of teacher's necessary in being successful in the assigned teaching environment $(\mathrm{RII}=0.81)$. The findings support Skinner's (2001) assertion that induction programmes are essential to make new employees to become better acquainted with the environment they are going to work in. On the other hand, the training programmes have not had any important impact in making them technologically oriented $(\mathrm{RII}=0.34)$ and enhancement in the orientation of the district curriculum $(\mathrm{RII}=0.39)$.

Impact of Induction Programmes on the Retention of Teachers

The intention of newly posted teachers to quit the teaching profession in the Biakoye District is studied in this section. Against this background, the study investigated the retention rate of newly posted teachers at the District, Circuit and School level. The results are presented in Table 6.

Table 6-Impacts of Induction Programmes on the Retention of Teachers

\begin{tabular}{lcccccc}
\hline & \multicolumn{2}{c}{ District } & \multicolumn{2}{c}{ Circuit } & \multicolumn{2}{c}{ School } \\
\cline { 2 - 7 } Responses & No. & $\%$ & No. & $\%$ & No. & $\%$ \\
\hline Very high & 11 & 5.0 & 4 & 1.8 & 44 & 20.0 \\
High & 80 & 36.4 & 124 & 56.4 & 95 & 43.2 \\
Low & 112 & 50.9 & 60 & 27.3 & 61 & 27.7 \\
Very low & 17 & 7.7 & 32 & 14.5 & 20 & 9.1 \\
\hline Total & 220 & 100 & 220 & 100 & 220 & 100 \\
\hline
\end{tabular}

Source: Field Survey, Appiah (2017)

Aggregating the results in Table 6 shows that while more than half $(58.6 \%)$ of the respondents rated the retention of newly posted teachers at the district level as low, more than half of the respondents rated the Circuit $(58.2 \%)$ and School (63.2\%) as high. The high attrition rate of newly posted teachers at the school level could possibly be explained by the fact that the organisation of induction programmes at the school level is low as compared to that at the district level. This finding is supporting the comments of Ingersoll and Kralik (2004) who posit that teachers tend to respond positively to the demands of their job when adequate orientation is given to them.

In this regard, the study further investigated the resignation intention of the respondents. The results are shown in Table 7.

Table 7-Resignation Intention of Respondents

\begin{tabular}{lcc}
\hline Resignation intention & Frequency (No.) & Percent (\%) \\
\hline Want to leave GES & 64 & 29.1 \\
Keep working as a teacher & 114 & 51.8 \\
I regret becoming a teacher & 42 & 19.1 \\
\hline Total & 220 & 100 \\
\hline
\end{tabular}

Source: Field Survey, Appiah (2017)

As contained in Table 7 , a little over half $(51.8 \%)$ of the respondents indicated that for the next few years, 
they would like to keep working as teachers in their schools while almost 30 percent want to leave the teaching profession but due to the lack of alternatives, they are compelled to remain. Generally, 48.2 percent of the newly posted teachers have the intention of leaving the profession. From the interviews with the key informants, it was also clear that there was some level of attrition among the new teachers. The District Director lamented that:

Even though the rates are not that high, sometimes you feel that if the opportunity is created for the newly posted teachers to leave the profession, some will readily opt out. This makes the induction relevant in at least minimizing their initial challenging in the profession.

The finding and the view of the director is incongruent with the submission of Lortie (1975) who asserted that teaching has traditionally been characterised as an occupation with high levels of attrition among newcomers. Relating the 29.1 percent of the respondents who want to leave but due to the lack of alternatives are compelled to remain to Mobley's Model of Turnover, it implies that once alternatives are encountered and the alternatives are favoured over the current job (teaching for the new teacher), the decision to quit could be made. The study further examined the resignation intention of the respondents across their demographics in other to see whether these demographic variables are related to respondents' resignation intention.

Table 8-Resignation Intention across Demographics

\begin{tabular}{|c|c|c|c|}
\hline Demographic Variables & Chi-square $\left(\chi^{2}\right)$ & Degree of Freedom (df) & Significance (p) \\
\hline Gender & 0.037 & 1 & 0.847 \\
\hline Education & 1.823 & 3 & 0.610 \\
\hline Teaching in the district & 0.228 & 3 & 0.973 \\
\hline Teaching in the school & 4.614 & 3 & 0.202 \\
\hline & 5.647 & 2 & 0.059 \\
\hline
\end{tabular}

Source: Field Survey, Appiah (2017)

As presented in Table 8 , it is noted that the number of years of teaching in the school had a marginal significant impact on their resignation intention $(\mathrm{p} \leq 0.05)$. In other words, in the exception of the number of years of teaching in the school, none of the demographic characteristics of the respondents influenced their intention of quitting from the teaching profession. Gender having an insignificant effect on the resignation intention of the respondents meant that the resignation intention is independent on gender. This is inconsistent with the submission of Tabs (2004) who asserted that male teachers are more likely to depart than female teachers. Furthermore, Johnson and Birkeland (2003) posited that a woman is more likely to remain in public school teaching than a man. The inconsistencies in the results as compared to this study could be explained by the variation in the study population. This study focused on newly posted teachers and retention in the teaching profession while Tabs (2004) and, Johnson and Birkeland (2003) concentrated on teachers who have been in the profession for some time.

Based on this, the study further performed the standardised residual in identifying the cells among the number of years of teaching in the school that had the major contribution to the resignation intention of the respondents. Using standardized residuals, only the cells on the $0-2$ years were the significant contributors to the chi-square relationship between number of years of teaching in the school and the resignation intention of the respondents. While all the respondents who had worked for at least three years were willing to keep working as teachers in their school, the majority of those who have worked for a maximum of two years want to leave Ghana Education Service but due to the lack of alternative, they were compelled to remain. This meant that the resignation intention of newly posted teachers with few years in teaching seemed to be higher than that of those with higher years. This is consistent with the arguments of the human capital theory that younger teachers are more likely to leave. This is the assertion by a head teacher who said that:

For the newly posted teachers, they are just moving from one school to the other, because they think they are still energetic and have more years to retirement. This is not so for those who have spent much years in the profession, they prefer to remain in one school provided they are at least

satisfy with the working conditions. Yes, I can say that the attrition rate among the newly posted teachers who are just a year or two is higher as compared to those who have spent like three years and above.

Using number of years of teaching in the current school as an indicator of experience, and that teachers who have been in the school for a long time are experienced in the school. The findings are consistent with the comments of DeAngelis and Presley (2010) who posit that teachers with less experience in their profession are more likely to leave the profession than their counterparts because the experience ultimately keeps teachers in the classroom. Teachers with long teaching experience are more likely to remain as indicated by the findings could be explained by Shen's (1997) assertion that new teachers possess less pedagogical knowledge than their more experienced colleagues, hence are more likely not to remain.

In this regard, it was important to specifically examine the key reasons surrounding the resignation intention of the respondents. The key issue emanated was neglected by the system. Some of the respondents were of the view that they are made to feel neglected and are not being cared for by the system since they were new in the 
system. One of the respondents lamented: You are made to feel like a stranger to the system and not sure of what to do, where to find relevant information and sometimes even who to fall on in terms of challenges.

The findings are consistent with the comments of Cobbold (2007) who posits that many beginning teachers think they are neglected by the system once they are posted to schools. Such neglect according to Ingersoll and Smith (2004), is unsuitable for the success and retention of beginning teachers.

- Poor inter-personal relationship between Ghana Education Service and the new teacher: Although it was noted that in some instances, newly posted teachers were inducted, generally, there have been poor relationships between the Ghana Education Service and the new teacher.

- Unreliable nature of Ghana Education Service: It was noted that the newly posted teachers have been stranded on a number of occasions and felt that Ghana Education Service has not been there for them. A new teacher complained:

I had fire outbreak and all my belongings got burnt, Ghana Education Service could not even offer me a Cedi not to talk of visiting me as a newly posted teacher who had no family and relatives in the town.

- Unattractive incentives: Also noted was the fact that Ghana Education Service has not made attractive incentives for newly posted teachers including logistics and allowances which must be given to teachers to enable them stay longer.

- Poor facilities: The facilities in the schools were also noted to be demotivating

\section{Impact of Induction Programmes on the Retention of Teachers}

The study also investigated the impact of the induction programmes on the retention of teachers. This was done by examining whether the quality of the induction, relevant content, positive attitude by teachers have had any impact on the retention of the teachers.

Table 9-Induction Programmes on the Retention to Teachers

\begin{tabular}{lcccccccc}
\hline & \multicolumn{2}{c}{ Quality } & \multicolumn{2}{c}{ Relevant } & \multicolumn{2}{c}{ Positive Attitudes } & \multicolumn{2}{c}{ Remain in School } \\
Responses & No. & $\%$ & No. & $\%$ & No. & $\%$ & No. & $\%$ \\
\hline Strongly disagree & 11 & 5.1 & 22 & 10.5 & 25 & 11.4 & 46 & 20.9 \\
Disagree & 54 & 24.5 & 29 & 13.2 & 40 & 18.2 & 46 & 20.9 \\
Agree & 76 & 34.5 & 95 & 43.2 & 76 & 34.5 & 95 & 43.2 \\
Strongly agree & 79 & 35.9 & 73 & 33.2 & 79 & 35.9 & 34 & 15.5 \\
Total & 220 & 100 & 220 & 100 & 220 & 100 & 220 & 100 \\
\hline
\end{tabular}

Source: Field Survey, Appiah (2017)

Table 9 shows that more than half of the respondents were of the view that the more quality the components of an induction experience by teacher $(70.4 \%)$, the higher the probability of retention and that the induction programmes are very relevant to the retention of teachers $(76.4 \%)$. Furthermore, teachers involved in induction programmes have more positive attitudes towards teaching $(70.4 \%)$ and that the induction programmes organised have helped them to remain in the school until now (58.7\%). These findings are consistent with the comments of Edmunds and Smith (2001) who posit that the more successful a beginning teacher and the quicker they experience success, the greater the likelihood they will remain in the teaching profession. The study further performed an ordinary linear regression analysis to determine if the induction programmes have had any significant effect on the retention of teacher. In this case, the variable which stated 'have you benefited from any induction programme at the school' was used as the independent variable while the resignation intention of the teachers was used as the dependent variable. A coefficient of determination (R Square) of 0.156 was obtained which implies that 15.6 percent of the variation in the resignation intention of the newly posted teachers was explained by them benefiting from an induction programme.

Table 10-Model Summary

\begin{tabular}{lccccc}
\hline Model & Sum of Squares & Df & Mean Square & F & Sig. \\
\hline Regression & 2.177 & 1 & 2.177 & 9.960 & 0.003 \\
Residual & 11.805 & & 54 & 0.219 & \\
Total & 13.982 & & 55 & & \\
\hline
\end{tabular}

Predictors: Resignation intention, $\mathrm{p}$ is significant at 0.05

Source: Field Survey, Appiah (2017)

As presented in Table 10, the analysis of the model summary implies that the regression model is significant $(\mathrm{p}<0.05)$. The coefficients analysis also shows that there is a significant and positive correlation $(\mathrm{F}=9.960, \mathrm{p}=$ 0.003 ) between the organisation of the induction programme and the resignation intention of the teachers. This meant that the more induction programmes are organised for newly posted teachers, the more the likelihood of retaining them in the teaching profession. The finding from the regression analysis is consistent with the comments 
of Wong (2002) who aver that the more quality components of induction experienced by a new teacher, the lower the probability of turnover. Furthermore, the findings are in line with Menchaca (2003) observation that the more components of induction experienced by a newly posted teacher, the lower the predicted probability of turnover. It was also noted that the leaving intention of the teachers had nothing to do with the induction programme and that they just are not intoned with the teaching profession. One of the teachers indicated: Some of the teachers would like to leave because teaching is not their field, they just got into the profession by circumstances such as lack of funds for pursuing tertiary education, poor academic record as well as lack of better job offers in the country.

\section{Conclusions}

The organisation of induction programmes for newly posted teachers have not been an integral component of teacher development in the District, although some attempts have been made in this regard. Although the induction programmes have not been largely delivered in response to teachers' emerging pedagogical needs, they have had important impact on the teaching outcomes of the teachers. The lack of expertise to design, implement and evaluate their induction programmes among head teachers coupled with limited resources are major challenges in undertaking induction programmes in the District.

In relation to the induction programmes and teacher retention, it is concluded that the more quality components of induction experienced by a new teacher, the lower the probability of turnover. Thus although the intention of the newly posted teacher to resign from the teaching profession is significantly influenced by the organisation of induction programme, there are other important factors that influence the resignation intention of the newly posted teacher.

\section{Recommendations}

The following recommendations are made for policy formulation based on the major findings that emerged from the study.

\section{Institutionalisation of induction policy}

Currently, there seems not to be a clear cut policy on the induction of newly posted teachers in the Ghana Education Service although there is a teacher posting policy for newly recruited teachers. This has resulted in Head Teachers and District Directors of Education using their own discretion to work out induction training programmes. To introduce some level of harmony and standardization in the induction process, a comprehensive policy on recruit teacher induction should be institutionalised by the In-service Training Department of the Ghana Education Service.

\section{Introduction of mentor-mentee relationship}

The District Director of Education in collaboration with the Head Teachers should introduce mentor-mentee relationship where experienced teachers are made to mentor newly posted teachers. Generally, the mentors are to serve as confidants and not evaluators; mentors should be concerned only with helping mentees to ultimately impact on their teaching outcomes. However, new teachers must feel confident in expressing doubts or admitting mistakes to experienced teachers, without fearing embarrassment or repercussions.

\section{Training and capacity building of head teachers in induction programmes}

Training and capacity building schemes through seminars, conferences, and academic institutions is an essential ingredient to provide head teachers with new induction techniques and methodologies necessary for the successful implementation of teaching outcomes. In this regard, the In-service Training Department of the Ghana Education Service through the District Director of Education is encouraged to invest in the career development of its head teachers in relation to the organisation of induction programmes for newly posted teachers. Prior to such training, it is important that training needs assessments of the head teachers are performed. This is essential to customise and individualise, whenever possible, to meet the unique needs of each head teacher. It is however, important that management evaluates the impact of these training programmes on new teachers teaching outcomes through the use of impact assessment methodologies such as observations, questionnaire, and work sample among others.

\section{Investment in induction training programmes for new teachers}

Investments in training programmes for new teachers have strong direct and indirect multiplier effects on the retention and teaching outcomes of the new teacher. For the Government of Ghana to sufficiently invest in teacher induction, the Government through the Ministry of Education should:

1. Envisage and articulate future induction development scenarios through the development of a mediumlong term new teacher induction infrastructure development plan.

2. Implement teacher development policies that are applied consistently and enable the private sector to 
invest with confidence in teacher induction projects.

\section{Coordinating and alignment of induction programmes among providers}

Coordinating and alignment of training programmes is central to achieving effective training outcomes. In this respect, a comprehensive review of teacher induction training providers' policies, strategies and activities should be undertaken by the Ghana Education Service. To achieve this, Ghana Education Service needs to undertake an audit of existing teacher induction training providers to ensure alignment with the objectives of the mission of teacher training to promote the integration of such programmes into all sectoral planning structures of the Ghana Education Service. This is essential to minimise duplications.

\section{References}

Adentwi, K. I. (2005). Curriculum development: An introduction. Bingdon, Oxo: Wilas Press Limited.

Barber, M., \& Mourshed, M. (2007). How the world's best-performing school systems comeout on top. London: McKinsey and Company.

Chapman, D. W., \& Hutcheso, M. S. (1982). Attrition from teaching careers: A discriminantanalysis. American Educational Research Journal, 19(1), 93-105.

Cobbold, C. (2007). Induction for teacher retention: A missing link in teacher education policy in Ghana. Postgraduate Journal of Education Research, 8(1), 7-18.

Cochran-Smith, M. (2004). The problem of teacher education. Journal of Teacher Education, 55(4), 295-299.

Darling-Hammond, L. (2003). Access to quality teaching: An analysis of inequality in California's public schools. Santa Clara Law Review, 43, 101-239.

Drew, C. J., Hardman, M. L., \& Hosp, J. L. (2008). Designing and conducting research in education. LA: Sage Publications.

Duodu, K. G., Nunes, A., Delgadillo, I., Parker, M. L., Mills, E. N. C., Belton, P. S., Taylor, J. R. N. (2002). Effect of grain structure and cooking on sorghum and maize in vitro protein digestibility. Journal of Cereal Science, $35,161-174$.

Edmund, P., Markus, B., \& Smith, M. A. (2001). International supply chain agility: Trade-offs between flexibility and uncertainty. International Journal of Operations and Production Management, 21(5/6), 823-839

Flippo, E. B. (1984). Personnel management. New York: Mc. Grow-Hill.

Goodlad, J. I. (1984). A place called school: Prospects for the future. New York: McGraw Hill.

Huling-Austin, L. (1990). Teacher induction programmes and internships: Handbook ofresearch on teacher education. New York: Macmillan.

Ingersoll, R. M. (2001). Teacher turnover and teacher shortages: An organisational analysis. American Educational Research Journal, 499-534.

Joerger, R. M., \& Bremer, C. D. (2001). Teacher induction programmes: A strategy forimproving the professional experience of beginning career and technical education teachers (Report No. RR1009). St. Paul, MN: National Research Centre for Careerand Technical Education, University of Minnesota.

Johnson, S. M., \& Birkeland, S. E. (2003). Pursuing a "sense of success": New teachers explain their career decisions. American Educational Research Journal, 40(3), 581-617.

Kavenuke, P. (2013). What is it that keeps good teachers in the teaching Profession: Areflection on teacher retention. International Journal of Social Sciences and Humanities, 4(1), 165-175.

Lawson, T. E. (1992). The competency initiative: Standards of excellence for human resource executives. Minneapolis, MN: Society for Human Resource Management.

Lortie, D. (1975). School teacher: A sociological study. Chicago, IL: University of Chicago Press.

Mcintyre, T. L. (2002). A model of levels of involvement and strategic roles of human resource development (HRD) professionals as facilitators of due diligence and the integration process. Human Resource Development Review, 3(2), 173-182.

O'Neill, D. K. (2004). Acting and planning on a false belief: Its effects on 3-year-old children's reasoning about their own false beliefs. Developmental Psychology, 40, 953-964.

Schultz, T. W. (1971). Investment in human capital. New York: Free Press.

Sekaran, U., \& Bougie, R. (2010). Research methods for business: A skill building approach. Hoboken, N. J.: Wiley and Sons.

Seyfarth, R. M. (1996). Social relationships among adult female baboons. Animal Behaviour, 24, 917-938.

Shen, Q. (1998). Induction programme for teachers: The case of newly promoted teachers. Physical Review Letter, $80,3268-3271$

Skinner, H. C. (2001). Functional behavioural assessment: Principles, procedures and future directions. School Psychology Review, 30(2), 156-172.

Smith, T., \& Ingersoll, R. (2004). The impact of induction and mentoring on beginning teacher turnover in high and low poverty schools. Paper presented at the annual meeting of the American Educational Research 
Association, San Diego, CA.

Steyn, G. M. (2004). How do professionals develop? Lessons for the effective implementation of the South African skills act. South African Journal of Education, 24(3), 217-224.

Steyn, G. M., \& Schulze, S. (2005). The induction of inexperienced teachers: Problems and needs. Acta Academica, 37(3), 234-259.

Tabs, E. D. (2004). Teacher attrition and mobility: Results from the teacher follow-up survey 2000-01. Washington, DC: U.S. Government Printing Office.

Watson, T. J. (2010). Critical social science, pragmatism and the realities of human resource management. The International Journal of Human Resource Management, 21(6), 915-931.

Wong, P. T. P. (2005). Creating a positive participatory climate: A meaning-centredcounselling perspective. In S. Schuman (Ed.), The IAF facilitation handbook (pp. 45-89). San Francisco, CA: Jossey-Bass. 